\title{
Webrings: círculos sociais de blogueiros na web
}

\author{
Jéssica Patrícia Silva de Sá \\ Universidade Federal de Minas Gerais, Escola de Ciência da Informação, Belo Horizonte, MG, Brasil \\ j.jessicadesa@gmail.com
}

DOI: https://doi.org/10.26512/rici.v13.n1.2020.23610

Recebido/Recibido/Received:2019-03-12

Aceitado/Aceptado/Accepted: 2020-01-17

Resumo: $O$ presente artigo objetiva discutir o conceito de webrings e compreender como ocorrem os processos de formação desses círculos sociais de blogueiros na web. Os blogueiros estabelecem relações virtuais entre si, ao lerem mutualmente seus blogs e entrarem em contato por meio de comentários, criando relações virtuais e comunidades. Baseada na etnografia virtual, essa pesquisa consistiu em uma imersão na blogosfera e na posterior realização de entrevistas com uma amostra de oito blogueiras. Os resultados e a discussão sobre os webrings pertencentes à blogosfera ressaltou a interação entre blogueiros, o compartilhamento de informação e as trocas comunicativas que ocorrem dentro desses círculos sociais. Verificou-se que, em grande parte dos casos, os webrings formam-se tanto de forma virtual como presencialmente, por meio de eventos e encontros presenciais. Dessa forma, a investigação de como se dá a formação dos webrings sugere a ampliação do conceito, incorporando a dinâmica atual das relações virtuais que ocorrem com influência das redes sociais.

Palavras-chave: Webrings. Blogueiros. Blogosfera.

\section{Webrings: social circles of bloggers on the web}

Abstract: This article aims to discuss the concept of webrings and how the processes of formation of these social circles of bloggers on the web. Bloggers establish virtual relationships with one another by reading their blogs on a one-to-one basis and getting in touch through comments, creating virtual relationships and communities. Based on virtual ethnography, this research consisted of immersion in the blogosphere, and subsequent interviews with eight bloggers. The results and the discussion about the webrings belonging to the blogosphere highlighted the interaction between bloggers, the sharing of information and the communicative exchanges that take place within these social circles. It has been found that, in most cases, webrings are formed both in virtual and in person, through events and faceto-face meetings. Thus, the investigation of how the webrings are formed suggests the extension of the concept, incorporating the current dynamics of the virtual relations that occur with the influence of the social networks.

Keywords: Webrings. Bloggers. Blogosphere.

\section{Webrings: círculos sociales de blogueros en la web}

Resumen: El presente artículo objetiva discutir el concepto de webrings y cómo ocurren los procesos de formación de esos círculos sociales de blogueros en la web. Los bloggers establecen relaciones virtuales entre sí, al leer mutuamente sus blogs y ponerse en contacto a través de comentarios, creando relaciones virtuales y comunidades. Basada en la etnografía virtual, esa investigación consistió en una inmersión en la blogosfera, y en la posterior realización de entrevistas con ocho blogueras. Los resultados y la discusión sobre los webrings pertenecientes a la blogosfera resaltó la interacción entre blogueros, el intercambio de información y los intercambios comunicativos que ocurren dentro de esos círculos sociales. Se verificó que, en gran parte de los casos, los webrings se forman tanto de forma virtual como presencialmente, por medio de eventos y encuentros presenciales. De esta forma, la investigación de cómo se da la formación de los webrings sugiere la ampliación del concepto, incorporando la dinámica actual de las relaciones virtuales que ocurren con influencia de las redes sociales.

Palabras clave: Webrings. Bloggers. Blogosfera. 


\section{Introdução}

No ambiente virtual os sujeitos lidam com a informação de diversas formas, inclusive compartilhando conteúdo e realizando trocas com outros atores na rede. Assim, surgem relações virtuais e comunidades. Segundo Recuero (2003), dessas relações virtuais surgem os webrings, conceito elaborado pela autora ao analisar as relações formadas entre os blogueiros na web. De acordo com a referida autora, os webrings são círculos sociais formados por blogueiros que interagem entre si.

[...] utilizamos o termo webring para definir círculos de bloggeiros que lêem seus blogs mutuamente e interagem nestes blogs através de ferramentas de comentários. Os blogs são linkados uns nos outros e formam um anel de interação diária, através da leitura e do comentário dos posts entre os vários indivíduos, que chegam a comentar os comentários uns dos outros ou mesmo deixar recados para terceiros nos blogs. Esse círculo de blogs difere, basicamente, de um grupo de links porque, como discutiremos adiante, o blog funciona como uma representação do bloggeiro no ciberespaço. Portanto, num webring, como o definimos aqui, temos um grupo de pessoas, mais do que um grupo de links (RECUERO, 2003, p. 7).

O presente artigo objetiva discutir o conceito de webrings e compreender como ocorrem os processos de formação desses círculos sociais na web. Para tal, apresentam-se os resultados parciais de uma pesquisa de mestrado intitulada "Ler e compartilhar na web: práticas informacionais de blogueiros literários", defendida em dezembro de 2018 junto ao Programa de Pós-Graduação em Ciência da Informação da Universidade Federal de Minas Gerais.

A pesquisa trata-se de um estudo qualitativo em profundidade que objetivou compreender as práticas informacionais de blogueiros administradores de blogs que abordavam a temática da literatura, visando entender os diversos modos como esses sujeitos lidam com a informação nos webrings pertencentes à blogosfera ${ }^{1}$. Não pretende-se aqui discorrer sobre todos os resultados dessa ampla pesquisa, e sim, discutir aqueles referentes ao objetivo específico: investigar como se dá a criação dos webrings.

\section{Contextualização teórica}

A formação de um webring se dá principalmente por meio da ferramenta de comentários, que possibilita a interação social. Inicialmente, o sujeito conhece o blog, navega pelas postagens e sente necessidade de interagir com o blogueiro autor do mesmo. Esse sujeito, leitor do blog, começa a conhecer o blogueiro e perceber que também existem outras pessoas interagindo com ele. Muitas vezes esse leitor também possui um blog, no qual se comunica com seus leitores. É assim que o círculo começa a ser formado. A partir da

\footnotetext{
${ }^{1}$ Comunidade de blogs e blogueiros.
} 
descoberta de um novo blog, o blogueiro passa a acessá-lo frequentemente e divulga o link em sua própria página, divulgando aquele blog para que todo o seu círculo de leitores possa também conhecê-lo. À medida que novos blogs são acrescentados às listas diárias dos usuários, novos webrings surgem. Um blogueiro pode pertencer a vários webrings (RECUERO, 2003).

Outros autores também observaram a formação de relações sociais entre os blogueiros, que formam grupos e comunidades. De acordo com Prange (2003), uma cumplicidade é desenvolvida por meio da seção de comentários, espaço privilegiado para as trocas entre os leitores, e se os visitantes forem também autores de outros blogs é estabelecida uma verdadeira rede de interação entre os blogueiros. O caráter público dos blogs, segundo a autora, oferece significativas possibilidades de interação. Dessa forma, as trocas costumam ocorrer de forma intensa, inclusive como estímulos para as atualizações diárias por parte dos autores. Segundo a autora, os grupos formados pelos blogueiros não são fechados e não tem definidos o número de participantes, assemelhando-se a redes.

A relação entre leitores e escritores de blogs também é estudada por Di Luccio e Nicolaci-da-Costa (2010, p. 140), que afirmam que "nos blogs, escritores e leitores se misturam e se fundem". De acordo com as autoras, escritores de blogs são também leitores de outros blogs. Muitos blogueiros eram incialmente leitores de blogs, que ficaram encantados com os recursos desse espaço textual virtual e decidiram criar seus próprios blogs. Ao descrever a interação entre os blogueiros, as autoras afirmam que blogueiros são como vizinhos que se visitam diariamente, lendo os posts uns dos outros e interagindo por meio de comentários. Assim, as visitas recíprocas a partir dos links disponíveis nos blogs é que possibilitam a qualidade dinâmica dos mesmos (DI LUCCIO; NICOLACI-DA-COSTA, 2010).

Já Araújo e Vieira (2012) consideram os webrings como redes sociais e descrevem como ocorrem a formação dessas relações. Os autores categorizam as relações formadas nos webrings, que podem ocorrer de forma unidirecional ou bidirecional. No primeiro tipo, a relação interativa entre os atores ocorre de forma isolada, onde um laço de interação acontece numa via de mão única. Por sua vez, na relação bidirecional ocorre um laço de interação mútuo entre os pares.Araújo e Vieira $(2012$, p. 5) descrevem a rede formada pelos blogueiros e como ocorrem a formação dessas relações:

Na rede de interações formam-se vínculos virtuais entre os atores, às vezes essa relação interativa ocorre de forma isolada onde um laço de interação acontece numa via de mão única, [...] é chamada de relação unidirecional. Mas, também ocorrem os casos em que essa relação se apresenta de forma recíproca, ou bidirecional, por exemplo, um determinado ator interage com um nó, com um link de saída para um blog e por sua vez o blog que recebeu 
o link, oferta um outro link de entrada para esse determinado ator, formado um laço de interação mútua entre os pares.

Entre os autores de blogs é comum a formação de grupos ou comunidades, sendo este mais um dos desdobramentos da escrita nos blogs. Esses grupos assemelham-se a redes e se formam, geralmente, a partir dos links indicados em cada um dos blogs. Estes links, além de encaminhar os leitores de um blog para outros, indicam os sites com os quais os autores têm alguma afinidade. Em alguns casos o vínculo de amizade já existia antes dos blogs e, em outros casos, esse vínculo é iniciado ou construído justamente no ambiente virtual (PRANGE, 2003).

Existem alguns elementos essenciais para que o blogueiro consiga inserir seu blog em uma rede de blogs. Primeiramente, o autor deve divulgar seu blog, fazendo uso dos recursos existentes na internet. Um dos recursos disponíveis é incluir o endereço eletrônico de seu blog em comentários deixados nos blogs de outros blogueiros, numa expectativa de reciprocidade, esperando a retribuição da visita e do comentário postado. Posteriormente, ao menos três outros movimentos parecem ser fundamentais para que o escritor/leitor entre no universo dos blogs: constante atualização dos posts, inclusão de links para outros blogs e visitas feitas a outros blogs, deixando comentários. Esses elementos demonstram a necessidade de atualização constante e apontam para a característica fundamental da interconexão (DI LUCCIO; NICOLACI-DA-COSTA, 2010).

Os webrings, na visão de Recuero (2003, p. 12), podem também ser compreendidos como comunidades virtuais "[...] porque todas as características estão presentes: a temporalidade das relações, uma vez que os blogs são atualizados frequentemente, bem como os comentários, que são feedbacks de cada post, e que representam a interação mútua possibilitada pelo sistema [...]". A autora compreende comunidade virtual como um grupo de pessoas que estabelecem relações sociais entre si, caracterizadas pela permanência no tempo que leva à construção de um corpo organizado, cuja comunicação é mediada por um computador e associada a um virtual settlement. Portanto, o primeiro passo para a formação da comunidade virtual é a formação de relações sociais através da interação mútua entre os indivíduos.

O conceito de Virtual Settlement é uma proposição de Quentin Jones (1997, on-line, citado por RECUERO, 2003). O virtual settlement "é um lugar demarcado no espaço, onde os indivíduos participantes da comunidade encontram-se para estabelecer as relações sociais, como por exemplo, uma sala de chat" (RECUERO, 2003, p. 6). Recuero (2003) utiliza esse conceito trazendo a perspectiva da criação de um lugar no ciberespaço, delimitações imaginárias constituídas por nós mesmos. Dessa forma, a autora compreende os blogs como representações espaciais do self, ou seja, o blog se constitui como demarcação de onde o 
blogueiro se encontra na web. Os blogs que costuma acessar e linkar são vistos como seus "vizinhos". Dessa forma, um webring, conforme Recuero (2003, p. 12), pode ser compreendido como um virtual settlement, pois os círculos de blogueiros que interagem, se relacionam e trocam informações entre si funcionam como um lugar, uma vizinhança.

\section{Metodologia}

Montardo e Passerino (2006) recomendam o uso da metodologia netnográfica em estudos de espaços de socialização na web, como os blogs. Segundo as autoras, a etnografia virtual é fundamental para oferecer um estudo mais aprofundado e completo, pois considera o universo pesquisado a partir de seus atores principais.

Baseada na etnografia virtual, a primeira etapa da coleta de dados consistiu em uma imersão na blogosfera literária. A partir dela, foi possível conhecer os blogs e os blogueiros, realizando uma análise documental por meio da leitura de postagens e comentários. Ao analisar o conteúdo textual, imagético e hipertextual presente nos blogs, buscou-se compreender como se configura o perfil de cada blog e que tipo de informação é veiculada pelo blogueiro.

A segunda etapa coleta de dados consistiu na realização das entrevistas semiestruturadas com as blogueiras responsáveis pelos blogs selecionados para a pesquisa, buscando entender as práticas do sujeito informacional do seu ponto de vista. Por meio de tais entrevistas pretendeu-se apreender as falas dos sujeitos no que se refere a como acontecem as interações entre os blogueiros possibilitando a formação dos webrings na blogosfera literária.

A amostra de blogueiros literários foi definida no 20 ㅇ \#Clube do Livro $\mathrm{BH}$, que aconteceu no dia 24 de fevereiro de 2018 na cidade de Belo Horizonte. O \#Clube do Livro BH é um evento literário de grande porte idealizado por uma blogueira literária, administradora do blog Coisas de Mineira. A listagem de 19 blogs advinda do evento foi analisada pela pesquisadora, que navegou pelos blogs e identificou se suas características eram condizentes com a proposição da pesquisa. Dessa forma, oito blogs foram considerados como possíveis de serem contemplados na pesquisa.

Como forma de preservar o sigilo das participantes, optou-se pela utilização de nomes fictícios para a identificação das blogueiras. Dessa forma, as entrevistadas foram identificadas por nomes inspirados em personagens femininas da literatura brasileira. Evidencia-se que não há relação entre a escolha dos nomes e as características pessoais das blogueiras.

No quadro 1 são apresentadas algumas características de cada uma das blogueiras entrevistadas, sendo também apresentados os oito blogs que fizeram parte da pesquisa: 
Entrando Numa Fria², Minha Estante e Muito Mais ${ }^{3}$, Marshmallow com Café4, DNA Literário ${ }^{5}$, Cultura Pocket ${ }^{6}$, Menina Compassiva ${ }^{7}$, Livros e Sushi ${ }^{8}$, Paradise Books 9 .

Quadro 1 - Perfil das entrevistadas

\begin{tabular}{|c|c|c|c|c|c|}
\hline Nome & Idade & Cidade & Profissão & $\begin{array}{c}\text { Ano em que } \\
\text { se tornou } \\
\text { blogueira }\end{array}$ & Blog \\
\hline Emília & 28 & Belo Horizonte & Advogada & 2008 & $\begin{array}{c}\text { Entrando Numa } \\
\text { Fria }\end{array}$ \\
\hline Lucíola & 31 & Belo Horizonte & Analista Contábil & 2015 & $\begin{array}{c}\text { Minha Estante e } \\
\text { Muito Mais }\end{array}$ \\
\hline Ana Terra & 22 & Belo Horizonte & $\begin{array}{l}\text { Estudante de } \\
\text { Fisioterapia }\end{array}$ & 2018 & $\begin{array}{l}\text { Marshmallow } \\
\text { com Café }\end{array}$ \\
\hline Gabriela & 20 & $\begin{array}{l}\text { Ribeirão das } \\
\text { Neves }\end{array}$ & $\begin{array}{l}\text { Estudante de } \\
\text { Jornalismo }\end{array}$ & 2016 & DNA Literário \\
\hline Macabéa & 36 & $\begin{array}{l}\text { Ribeirão das } \\
\text { Neves }\end{array}$ & Administradora & 2017 & Cultura Pocket \\
\hline Capitu & 21 & Contagem & $\begin{array}{l}\text { Estudante de } \\
\text { Design Gráfico }\end{array}$ & 2013 & $\begin{array}{c}\text { Menina } \\
\text { Compassiva }\end{array}$ \\
\hline Iracema & 32 & Belo Horizonte & $\begin{array}{l}\text { Analista de } \\
\text { Processos }\end{array}$ & 2014 & Livros e Sushi \\
\hline Ceci & 32 & Belo Horizonte & $\begin{array}{c}\text { Professora de } \\
\text { Circo }\end{array}$ & 2015 & Paradise Books \\
\hline
\end{tabular}

Fonte: Elaborado pela autora.

\section{Resultados e discussão}

Como já visto anteriormente, Recuero (2003) considera que um webring começa a ser formado quando um leitor conhece o blog e, ao ler os posts, sente a necessidade de interagir com o blogueiro e deixar um comentário. Esse leitor também é um blogueiro que, ao comentar, deixa o link de seu blog pessoal. O círculo de blogueiros se forma quando o blogueiro autor daquele blog lê o comentário e se interessa em saber quem é. Ao descobrir

\footnotetext{
${ }^{2}$ Disponível em: http://www.entrandonumafria.com.br/. Acesso em:10 mar. 2019.

${ }_{3}^{3}$ Disponível em: http://minhaestanteemuitomais.blogspot.com/. Acesso em:10 mar. 2019.

${ }^{4}$ Disponível em: http://www.marshmallowcomcafe.com.br/. Acesso em:10 mar. 2019.

${ }^{5}$ Disponível em: https://dna-literario.blogspot.com/. Acesso em:10 mar. 2019.

${ }^{6}$ Disponível em: https://culturapocket.blogspot.com/. Acesso em:10 mar. 2019.

7Disponível em: https://meninacompassiva.blogspot.com/. Acesso em:10 mar. 2019.

${ }^{8}$ Disponivel em: https://livrosesushi.wordpress.com/. Acesso em:10 mar. 2019.

${ }^{9}$ Disponível em: http://www.paradisebooks.com.br. Acesso em:10 mar. 2019.
} 
esse novo blog, o blogueiro passa a acessá-lo com frequência, o que promove uma interação entre os sujeitos.

Ao verificar os blogs da pesquisa, é possível identificar com facilidade comentários nos quais blogueiros deixam o link de seus respectivos blogs literários. Normalmente são feitos elogios à postagem e comentários gerais demonstrando um interesse pelo conteúdo resenhado e pelo blog. Essa prática é muito comum e foi encontrada na maior parte dos blogs durante o período analisado e até mesmo posteriormente, com exceção dos blogs Minha Estante e Muito Mais e Entrando Numa Fria. Na figura 1 são apresentados dois exemplos de comentários que possuem links para outros blogs.

Figura 1 - Link de blogueiras nos comentários dos blogs

a)

ด เ

Nossa também estou apaixonada por Riverdale, tinha tempo que uma série nầo me prendia tanto Seu blog è muito lindo. Se puder venha conhecer o meu Luisa - https://26motivospara. blogspot.con

b)

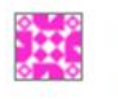

Thayenne

17 de setembro de 2018 as 13:07

Oló.

Sou louca para ler essa série, vejo algumas imagens das tirinhas e fico morrendo de rir, pois super me identifico com elas. Acho que será uma leitura descontraída e interessante, além é claro de terem ilustrações lindas e uma edição caprichada.

Beijos.

oculoselivrosblog.blogspot.com.br/

$\star$ Curtir

Legenda: a) Comentário de uma blogueira na postagem de Capitu.

b) Comentário de uma blogueira na postagem de Iracema.

Fonte: Blog Menina Compassiva ${ }^{10}$ e blog Livros e Sushi ${ }^{11}, 2018$.

Esse tipo de comentário, feito por blogueiros, apresenta um convite para a visita de seus respectivos blogs. Algumas blogueiras entrevistadas, aceitam o convite e clicam no link, sendo direcionadas para a página do outro blog.

CAPITU: Visito. Aí eu geralmente salvo uma pastinha que eu tenho lá de blogs, aí eu coloco todos. Aí eu não visito com muita frequência, por causa de falta de tempo mesmo, mas eu gosto de olhar, de saber o que as pessoas

10 Disponível em: <https://meninacompassiva.blogspot.com/2018/08/resenha-riverdalenetflix.html\#comment-form>. Acesso em: 14 out. 2018.

11 Disponível em: <https://livrosesushi.wordpress.com/2018/08/11/resenha-a-louca-dos-gatos-sarahandersen/comment-page-1/\#comment-5958>. Acesso em: 14 out. 2018. 
tão postando, de saber o que é entre aspas tendência, os livros que as pessoas tão lendo mais, eu gosto de ver.

IRACEMA: Sim, dou uma olhadinha. Já teve várias vezes de blogs iniciantes até pra fazer público né, pra se apresentar, eles falam 'Ah tô te seguindo me segue de volta', aí eu até falo 'Ah vou te ajudar', sigo. Eu não ligo pra isso não, tipo acho que todo mundo no começo precisa de ajuda, uma curtida, um seguidor vale muito sabe, é difícil.

CECl: Entro no link pra ver e retribuir. Porque existe muito essa coisa de retribuição de comentários também, às vezes a pessoa vai no seu blog e comenta, deixa o link dela. Você retribui o comentário, vai no blog dela.

Apesar de visitarem o outro blog, as blogueiras não se mostram genuinamente interessadas em conhecer o blog ou o blogueiro, pois afirmam que o fazem para retribuir a visita, ajudar o blogueiro iniciante e incentivá-lo. Ao alegarem que não visitam os blogs com frequência e só dão uma "olhadinha", as blogueiras demonstram que não estão efetivamente interagindo com esses outros blogueiros, ou seja, não estão constituindo webrings desse modo.

MACABÉA:Ah, depende. Igual eu te falei, se é alguém que eu conheço, que eu valorizo... Agora se é alguém que entrou só pra deixar o link, às vezes eu não vou não. Porque assim, blog tem muito disso, às vezes tem gente que entra faz o comentário, deixa o link dele só pra você poder ir no blog dele. Eu nem conheço, não sei quem é e tal, aí eu não vou não. Se eu ficar interessada, se o comentário for pertinente, eu perceber que a pessoa realmente se deu ao trabalho de ler, aí às vezes eu visito, e às vezes tem surpresas boas, sabe.

No relato acima, a blogueira apresenta certa desconfiança em entrar em um blog de uma pessoa desconhecida, preferindo visitar blogs de amigos. No mesmo sentido, outras blogueiras afirmam não visitar nenhum blog cujo blogueiro deixou o link nos comentários. Essa prática é interpretada como uma forma do blogueiro se promover, pedindo visitações de forma pública, atingindo os leitores do outro blog e fazendo um tipo de propaganda em cima do conteúdo produzido por um outro blogueiro.

EMÍLIA: A partir do momento que me pediu uma visitação, principalmente pública, foi lá no comentário do blog e pediu pra visitar, eu não visito. Não, não visito. Porque se quer pedir que eu te visito, manda inbox no Facebook, manda inbox no Instagram, por e-mail, não manda público não. Porque na verdade a pessoa não tá pedindo pra você visitar, tá pendido pros seus leitores visitarem.

LUCÍOLA: Eu vejo muita gente falando 'Nossa que legal, eu também escrevo' e coloca o link do blog embaixo. Isso eu acho feio, eu não faço esse tipo de coisa [...]. Eu acho que esse tipo de pessoa ela quer se promover em cima de uma outra pessoa, ela quer se promover em cima do conteúdo de uma outra pessoa. 
Somente uma das blogueiras demonstrou vincular-se a outros blogueiros da forma descrita por Recuero (2003), afirmando que entra no link deixado nos comentários de sua página, conhece o blog de outra blogueira, comenta na postagem e também deixa o link do seu respectivo blog.

GABRIELA: Eu entro, com certeza. Se ela veio no meu né, por que não ir no dela? Eu acho que faz parte, eu acho que é importante né, você incentivar outra pessoa também. Eu entro e comento. [...] Então, virtual geralmente a gente comenta o post uma da outra, deixa o link do blog.

Constata-se que, no caso das demais blogueiras entrevistadas, a formação de webrings não ocorre de acordo com o processo descrito por Recuero (2003). Evidencia-se que essas blogueiras participam de webrings, contudo, esses círculos sociais não se constituem por meio de links deixados por outros blogueiros nos comentários. Assim, para compreender como os webrings são constituídos nesses casos, foi perguntado às blogueiras quais as situações que permitem a criação de vínculos entre os blogueiros literários.

$\mathrm{Na}$ maioria dos casos relatados, os webrings são formados de duas maneiras: presencial e virtual. Um webring, conforme Recuero (2003), trata-se de um grupo de pessoas, mais do que um grupo de links. Esse grupo de blogueiros é caracterizado pela interação entre os sujeitos, agregando o suporte tecnológico do blog e os comentários. Apesar do forte viés virtual que caracteriza um webring, constatou-se que nada impede que um círculo de blogueiros surja de maneira presencial, por meio de eventos literários que promovem diversos encontros, nos quais os blogueiros se conhecem e mantêm contato. Certamente, o círculo de blogueiros presencial resulta em uma imersão virtual posterior, uma vez que os blogueiros irão manter contato e visitar mutuamente seus blogs através do suporte tecnológico.

Para uma das blogueiras, os webrings são formados em encontros presenciais e depois transportados para o ambiente virtual.

CAPITU: Eu fiz amizades físicas com o blog. Porque aí com o blog, eu comecei a vir no Clube no Livro [BH]. No Clube do Livro, eu conheci outras blogueiras. Mas pessoas que eu conheci no blog virtualmente eu não tive contato, eu só respondo como blogueira mesmo [...]. E aí a gente vai conhecendo o pessoal assim através de eventos mesmo, vitualmente não.

A importância do contato com outros blogueiros, tanto na forma presencial como na forma virtual é evidenciada nos depoimentos abaixo. Os encontros de leitores são relatados pelas blogueiras, que também descrevem as interações que ocorrem por meio da web.

ANA TERRA: Eu acho que é um pouco de cada. Porque pela internet você pode conhecer uma infinidade de coisas sem sair da sua casa, sem sair... Ou então você tá na rua, tá com o celular na mão, você consegue ler uma coisa que alguém do outro lado do mundo publicou. $E$ a questão de você tá num evento e conhecer alguém num evento ela cria uma relação diferente né, eu 
te conheci, eu soube que você trabalha com tal coisa, então eu vou procurar porque eu achei interessante, não foi nada que apareceu pra mim.

GABRIELA: Então, virtual geralmente a gente comenta o post uma da outra, deixa o link do blog. E pessoalmente, Clube do Livro, é... Esses eventos literários tipo Café com Leitura, Romances de época, essas coisas. Então geralmente tem espaço pra 'Ah quem é blogueiro quer deixar marcador de página ${ }^{12}$ aqui?'. Eu ainda não tenho, mas quem tem deixa lá o marcador e fala do blog mesmo. Tipo as meninas do Clube do Livro [BH] sempre falam 'Ah quem é blogueira?' Aí chega lá na frente e fala, entendeu.

LUCíOLA: Alguns [blogueiros] sim, porque é mais fácil quando moram perto. Os de Belo Horizonte, a gente acaba se encontrando em eventos, no próprio Clube [Clube do Livro $\mathrm{BH}$ ] ou em eventos tipo encontro de fãs de alguma editora, por exemplo, teve encontro da Jane Austen, teve encontro de fãs da Darkside, teve há pouco tempo da Passarela da Companhia das Letras né, do selo Passarela. Então assim a gente se encontra nessas coisas assim. Ou em grupos do WhatsApp, pelo WhatsApp mesmo.

Quanto às relações presenciais, as bienais do livro foram lembradas pelas blogueiras como uma possibilidade para estreitar laços entre os blogueiros, seja para ter uma companhia durante a viagem, para conhecer blogueiros no próprio evento ou encontrar pessoalmente amigos virtuais.

IRACEMA: Também eventos até fora de Belo Horizonte, companhia pra ir pra Bienal né, às vezes é muito ruim viajar sozinha, então eu acho que com certeza aproxima [...]. Acho que evento, sorteios, afinidade de gênero literário.

EMÍLIA: Muitos eventos, Bienal. Gente, Bienal é ótimo pra isso, porque na hora que você assusta tipo você tá conhecendo pessoas que você conversa na rede social há anos. Ou então, às vezes pessoas que você não conversa, mas que às vezes conhecem seu trabalho [...]. Então acaba que você tem um contato com pessoas que você não conversa na rede social. Então Bienal é a melhor coisa do mundo pra você se encontrar com as pessoas.

Em contrapartida, uma das blogueiras destaca que nos eventos literários nem sempre é possível identificar quem são os blogueiros presentes. Apesar de considerar os eventos literários como importantes pontos de encontro, Macabéa considera que é mais fácil criar vínculos com outros blogueiros de forma virtual.

MACABÉA: Em evento a gente encontra muito, mas é engraçado, porque eu não sei assim se as pessoas têm vergonha [...]. O povo escreve, o povo posta nos Instagram, mas ninguém fala que escreve. Você vai nos eventos tá cheio de gente lá que tem blog, ninguém fala nada.

\footnotetext{
12 É uma prática comum entre os blogueiros literários a confecção de marcadores de páginas com o logotipo do blog. Esses marcadores são distribuídos em eventos literários como forma de promover o blog. As blogueiras do Entrando Numa Fria e do Livros e Sushi entregaram seus respectivos marcadores de página para a pesquisadora.
} 
Virtualmente, os webrings são formados através dos blogs e também pelas redes sociais, como os grupos de blogueiros no Facebook e no aplicativo WhatsApp. A dificuldade em se encontrar pessoalmente com blogueiros que moram em regiões distantes é também destacada pelas blogueiras como um dos motivos da permanência do contato virtual. As parcerias entre os blogs, como, por exemplo, para realização de sorteios virtuais, também foi lembrada por possibilitar a criação de vínculos entre as blogueiras.

CECl: Virtualmente. Porque tem muitos de outros estados, que você só consegue ver durante os eventos, como na Bienal de São Paulo e Rio, que sai do Brasil inteiro que vai pra lá. Então a gente tem o contato mais virtual do que presencial.

PESQUISADORA: Aí você mantém contato pelas redes sociais, pelo WhatsApp?

CECl: Tudo, tudo. Pelo blog, pelo Face, pelo grupo de trocas de marcadores de livros.

MACABÉA: Acho que os grupos [Facebook], os sorteios, você faz um sorteio em parceria ou você faz um post em parceria, tipo uma parte do post tá no seu blog, o restante ou um outro comentário vai tá no outro blog, aí você deixa o link ali pra pessoa ir pra aquele outro blog. Então isso eu acho que é algo que ajuda.

IRACEMA: E também sorteio, fazer sorteio juntos porque o custo fica dividido e até mesmo um alavanca o outro, por exemplo o da Emília é maior que o meu, me ajudaria entendeu, e talvez o meu público que tá participando não é o público dela e acaba que ajuda ela também. Então acho que é isso [...]. Eu acho que... Hoje em dia a gente é muito virtual, a gente tá numa mesa a gente não conversa, prefere conversar no celular. Hoje em dia eu acho que é a tendência assim, eu acho que é isso, entendeu. E é muito difícil de encontrar.

Ana Terra conta sobre os webrings formados por meio de grupos no Facebook. Os blogueiros possuem uma parceria virtual, na qual toda semana os blogs parceiros visitam o blog de Ana Terra e uma das blogueiras do Marshmallow com Café visita os blogs amigos. Essa parceria pode explicar o grande número de comentários recebidos pelo blog e a predominância de comentários feitos por blogueiros.

ANA TERRA: Então, tem uma parceria que a gente fez com o pessoal do Clube do Livro, que foi pelo Facebook, que as meninas entraram em contado com a gente, mas é troca de experiências nos blogs. Então, a Yasmin ${ }^{13}$ é responsável por visitar os blogs parceiros e aí os blogs parceiros têm essa mesma obrigação de visitar a gente e comentar o que a gente tá falando. Isso, nas nossas publicações não sai. Isso é do grupo lá fechado, que as meninas firmaram, sabe. É um compromisso mais verbal, de eu ir lá toda semana te visitar e você vim cá toda semana me visitar.

Conclui-se que, no caso das blogueiras participantes da pesquisa, a formação de webrings ocorre virtualmente e também presencialmente, sendo depois transportada para o

\footnotetext{
${ }^{13}$ Nome fictício.
} 
meio virtual. De fato, as interações entre blogueiros ocorrem predominantemente de forma virtual, por meio dos blogs e das redes sociais, mas é importante ressaltar a importância que as blogueiras entrevistadas atribuíram aos eventos literários, que permitem o encontro presencial de círculos de blogueiros e também a criação de novos contatos.

Com o objetivo de fazer um mapeamento dos webrings identificados na pesquisa, foram consideradas as relações nas quais as blogueiras demonstraram algum tipo de interação e não meramente a leitura de outros blogs. Durante a análise documental, identificou-se a divulgação de links de blogs parceiros na forma de blogrolls. Entretanto, muitos desses não foram sequer citados pelas entrevistadas quando abordada a temática da interação entre blogueiros, de forma que foram considerados como troca de divulgação, e não como webrings propriamente ditos. Nos comentários das postagens é possível ver algumas interações entre blogueiros. Contudo, não foi possível averiguar se essa relação é mútua, uma vez que não foram analisados os demais blogs, para que fosse possível constatar se as blogueiras entrevistadas também os visitaram e interagiram com seus administradores. No decorrer das entrevistas, as blogueiras citaram nomes de blogs e blogueiros com os quais interagem. Dessa forma, considerou-se a fala das blogueiras como a principal fonte de informação sobre as interações mais profundas, que constituem os verdadeiros webrings.

Na figura 2 é possível ver os webrings formados pelas blogueiras participantes da pesquisa. Apesar de os webrings serem constituídos por grupos de pessoas, optou-se por apresentar o esquema com o nome dos blogs ao invés do nome dos blogueiros, de forma a simplificar a compreensão, visto que muitos dos blogs são coletivos.

Devido à amostra da pesquisa ser advinda de um evento literário, no caso o 20 \#Clube do Livro $\mathrm{BH}$, existe uma conexão entre os blogs, de forma que muitas blogueiras se conhecem. As blogueiras de Entrando Numa Fria, Livros e Sushi e Paradise Books constituem um webring juntamente com o blogueiro de Eu Conto Depois. Também existe um webring formado por Paradise Books e DNA Literário. As duas blogueiras de Ribeirão das Neves, dos blogs DNA Literário e Cultura Pocket também formam um webring. As blogueiras de Marshmallow com Café e a blogueira do Menina Compassiva formam um webring juntamente com as blogueiras do Coisas de Mineira. A blogueira do Minha Estante e Muito Mais é a única que não se relaciona com nenhuma outra blogueira da pesquisa, mas pertence a um webring com as blogueiras do Coisas de Mineira. Ressalta-se que todas as blogueiras entrevistadas possuem vínculos com outros blogueiros, ou seja, participam de webrings. 
Figura 2 - Webrings identificados na pesquisa

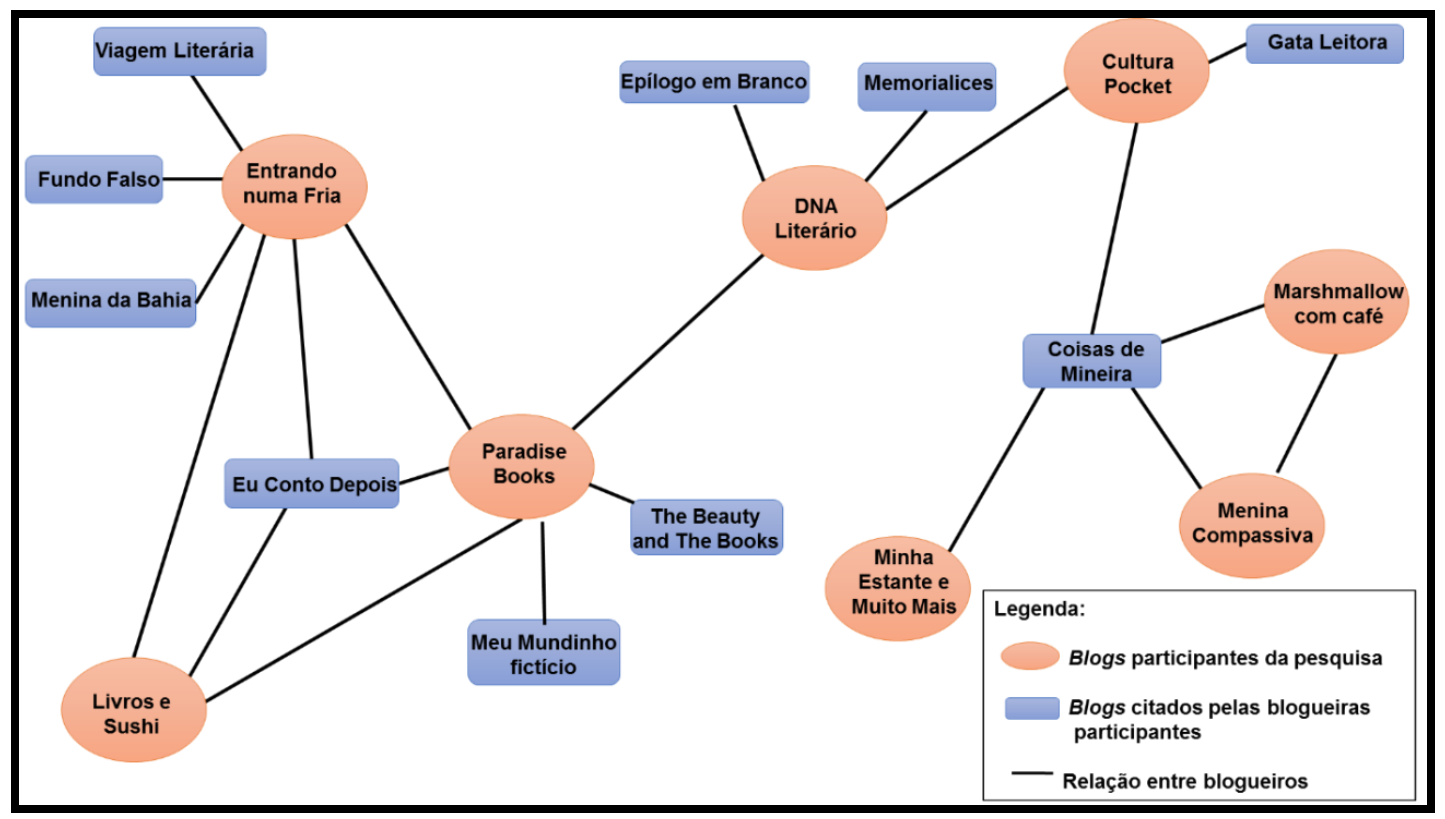

Fonte: Elaborado pela autora com base nos dados das entrevistas.

De acordo com Recuero (2004), vários webrings podem ter nós (blogs) em comum, como por exemplo, as blogueiras dos blogs Paradise Books, DNA Literário, Cultura Pocket e Coisas de Mineira, que pertencem a mais de um webring. Todos os blogs analisados possuem webrings com blogueiros que não fazem parte da pesquisa, pois um webring pode ser constituído de várias redes (RECUERO, 2004).

Conclui-se que a figura 2 apresenta somente uma parte de uma extensa rede de conexões entre os blogs literários. Ressalta-se que o esquema representa as interações entre os blogueiros no momento presente, estando sujeito a diversas alterações no decorrer do tempo, onde vínculos serão desfeitos e novos webrings se formarão.

Os dados da pesquisa sugerem uma ampliação do conceito de webrings. Recuero (2003) definiu os webrings como círculos sociais constituídos por blogueiros, que interagem por meio dos seus blogs e comentários. A autora identificou que a formação desses círculos sociais ocorria por meio dos links deixados por outros blogueiros nos comentários das postagens de um blog. Contudo, a maioria das participantes da pesquisa demonstrou que não constitui webrings desse modo, não possuindo genuíno interesse pelos links deixados em seus blogs ou julgando-os como uma estratégia de promoção de outro blog.

Atualmente, conforme os dados da pesquisa, devido ao fenômeno transmídia, o blog está vinculado a diversas mídias sociais, que possibilitam o contato virtual entre blogueiros, de forma que as relações não acontecem somente através dos comentários na plataforma do 
blog. Dessa forma, os blogueiros podem se conhecer e interagir por meio das redes sociais (Facebook, Instagram, YouTube, Twitter), formando webrings.

Além disso, círculos sociais de blogueiros são formados presencialmente, nos diversos eventos literários, e posteriormente são transportados para o ambiente virtual. Como Recuero (2003) afirma que os webrings são grupos de pessoas, mais do que um grupo de links, compreende-se que esse conceito possa ser aplicado às relações entre blogueiros que se iniciam de forma presencial e ocorrem predominantemente no meio virtual.

\section{Considerações finais}

A investigação de como se dá a criação dos webrings apresentou alguns resultados diferentes do referencial teórico. É importante ressaltar que grande parte desse referencial, sobretudo o trabalho de Recuero, foi escrito há mais de 15 anos, quando os elementos e dinâmica da blogosfera eram diferenciados. Atualmente, existe uma grande conexão entre a blogosfera e as redes sociais que altera a dinâmica de formação dos webrings, além de uma organização dos blogueiros para o agendamento de encontros presenciais. Dessa forma, afirma-se que o trabalho de Recuero (2003), que conceituou os webrings, é de extrema importância, contudo, uma época diferente exige uma ampliação desse conceito.

A discussão sobre os webrings pertencentes à blogosfera literária ressaltou a interação entre blogueiros literários, o compartilhamento de informação e as trocas comunicativas que ocorrem dentro desses círculos sociais. Verificou-se que, em grande parte dos casos, os webrings formam-se tanto de forma virtual como presencialmente, por meio dos eventos literários. Entretanto, a interação entre blogueiros acontece predominantemente no meio virtual, por meio das diversas mídias sociais.

Nesse sentido, a pesquisa evidenciou a possibilidade da ampliação do conceito de webrings cunhado por Recuero (2003). Atualmente, os círculos sociais de blogueiros não formam-se somente por meio da plataforma do blog, sendo constituídos através das diversas redes sociais vinculadas a ele, que ampliam as possibilidades de comunicação entre os blogueiros, que antes entravam em contato somente pelos comentários das postagens. Por outro lado, como os webrings são grupos de pessoas, compreende-se que o conceito possa ser aplicado também aos grupos de blogueiros que entram em contato por meio de encontros presenciais e mantêm relações virtuais.

Além disso, é possível compreender que o conceito de webrings foi associado a relações entre blogueiros devido à época em que foi elaborado, uma vez que a popularização e multiplicação dos blogs aconteceu no Brasil entre os anos de 2000 e 2001 (DI LUCCIO; NICOLACI-DA-COSTA, 2010). Hoje, haveria a possibilidade de aplicar a concepção de webrings a 
outros grupos de produtores de conteúdo virtual, uma vez que o conceito é compreendido como círculos sociais formados através da interação entre os sujeitos na web, por meio de ferramentas de comunicação e links, conquistando um determinado "lugar" na rede. Dessa forma, é perceptível a possibilidade de aplicação desse conceito não somente à blogueiros, mas também a outras comunidades que se formam na web a partir de interações em diversos canais e plataformas, como ocorre nas redes sociais.

Nesse sentido, a partir da análise dos dados da pesquisa, é possível atualizar o conceito de webrings e fazer uma proposta conceitual baseada na concepção original de Recuero (2003). Atualmente, é possível compreender os webrings como círculos sociais formados por produtores de conteúdo virtual que interagem na web por meio de uma multiplicidade de plataformas, formando canais de trocas comunicativas, assemelhando-se a redes. Os webrings podem ser formados no próprio meio virtual, através do contato por meio das ferramentas de comunicação presentes nos sites, blogs e redes sociais. Também existe a possibilidade da formação de webrings de forma presencial, a partir de encontros pessoais como, por exemplo, em eventos diversos, que tornam possível os sujeitos se conhecerem e, posteriormente, transportarem sua relação para o meio virtual. Contudo, um webring é caracterizado pela interação que ocorre predominantemente de forma virtual e contínua. Esses sujeitos produtores de conteúdo virtual formam um anel de interação diária, por meio do acesso aos conteúdos uns dos outros, realizando o intercâmbio de ideias e opiniões, influenciando-se mutuamente e construindo redes de socialização na internet.

\section{Referências}

ARAÚJO, Ronaldo Ferreira de; VIEIRA, Rosiene Marques. Blogosfera como rede social: análise da interatividade dos blogs de Alagoas. Revista Informe: Estudos em Biblioteconomia e Gestão da Informação, Recife, v. 1, n. 1, p. 65-77, 2012. Disponível em:

https://periodicos.ufpe.br/revistas/INF/article/download/44/82 Acesso em: 19 out. 2018.

DI LUCCIO, Flávia; NICOLACI-DA-COSTA, Ana Maria. Blogs: De diários pessoais a comunidades virtuais de escritores/leitores. Psicologia Ciência e Profissão, Rio de Janeiro, v. 30, n. 1, p. 132145, 2010. Disponível em: http://www.scielo.br/pdf/pcp/v30n1/v30n1a10 Acesso em: 4 set. 2018.

MONTARDO, Sandra Portella; PASSERINO, Liliana Maria . Estudo de blogs a partir da netnografia: possibilidades e limitações.Revista Novas Tecnologias na Educação, v. 4, n. 2 , 2006. Disponível em: http://www.cinted.ufrgs.br/renote/dez2006/artigosrenote/25065.pdf Acesso em: 9 set. 2019.

PRANGE, Ana Paula Lobão. Da literatura aos blogs: um passeio pelo território da escrita de si. 2003. 129 f. Dissertação (Metrado em Psicologia) - Departamento de Psicologia, Pontifícia Universidade Católica do Rio de Janeiro. Rio de Janeiro, 2003. Disponível em: https://www.maxwell.vrac.puc-rio.br/4084/4084_1.PDF Acesso em 20 out. 2018. 
RECUERO, Raquel da Cunha. Weblogs, Webrings e comunidades virtuais. Revista 404notFound, v. 1, n. 31, 2003. Disponível em: http://www.raquelrecuero.com/artigos.html Acesso em: 13 out. 2018.

RECUERO, Raquel da Cunha. Webrings: As Redes de Sociabilidade e os Weblogs. Sessões do Imaginário, Porto Alegre, v. 9, n. 11, 2004. Disponível em:

http://revistaseletronicas.pucrs.br/ojs/index.php/famecos/article/view/806/9000 Acesso em: 8 set. 2019. 